\title{
Loyalty towards online games, gaming addiction, and purchase intention towards online mobile in-game features
}

\begin{abstract}
The most important stream of game developers' revenue is arguably via gamer's in-game purchases. Previous literature has identified a number of strong determinants of online purchase intention including values, consumer experience, lifestyle, security, perceived risk, information, and subjective norms and behavioural control. The present study examined the relationship between online mobile gaming addiction and loyalty towards purchase intention of online mobile game in-game apps. The present study comprised 430 students from two major Indian universities who completed a short 28 -item survey focusing on three variables (i.e., addiction, loyalty towards online games, and purchase intention towards online mobile in-game features). The results demonstrated that (i) online mobile game addiction shared a significant positive relationship with online mobile game loyalty; (ii) online mobile game addiction had a positive relationship with the purchase of online mobile in-game apps, and (iii) online mobile game loyalty increased game users' intention to purchase online mobile ingame apps. The present study is the first to investigate loyalty and gaming addiction in relation to the purchase of in-game apps. Game developers will always want to facilitate loyalty among its clientele. However, if the engagement strategies used by gaming operators facilitate addiction as a way of increasing purchase intention of online mobile game in-game apps, this raises serious ethical questions which the gaming industry need to address as part of its corporate social responsibility strategy.
\end{abstract}

Keywords: Online mobile games, game addiction, game loyalty, in-game purchases, mobile game purchases 


\section{Introduction}

Online mobile games generate revenue through a number of different ways. Arguably, the most important stream of game developers' revenue is through mobile in-game purchases. In the digital world, extensive mobile in-game purchasers are called 'whales'. Game developers tend to focus on these whales to generate higher revenue through in-game purchases. It has been estimated that mobile app store revenue will amount to $\$ 69.7$ billion by end of 2020 (Statistica, 2016). Moreover, the same source forecasts that the revenue via app stores and ingame advertising may rise to $\$ 188.9$ billion (U.S.) by 2020 . Unlike other traditional or digital purchase systems, an in-game purchase is more dependent upon players' engagement with the game. The more the engagement, the more it stimulates the whales to go for in-game purchases.

Rajala et al. (2007) discussed three types of mobile games namely, standalone games, serverbased games, and streamed games. Online mobile games can fall under any of these categories. The revenue pattern and business model will be different for each category because a single business model cannot be applied for all mobile games (Willson \& Leaver, 2016). It has also been noted that online mobile games can broadly make money through three major categories; paid application download (Gainsbury et al., 2016), in-game purchases (Alha et al., 2016; Hsiao \& Chen, 2016), and advertising (Hofacker et al., 2016; Lin, 2014). Despite research having focused on addressing the factors affecting users' attitude towards mobile advertising (Tsang et al., 2004; Leppaniemi and Karjaluoto, 2005) and users' intention to pay for mobile applications (West et al., 2012; Hsu and Lin, 2015), there has been limited attention given to understanding user behaviour towards in-game purchases.

It has been reported that $90 \%$ of the Google Play's revenue is from online mobile games (Android Authority, 2016). Online mobile games have gained increasing coverage from 
industry and research perspectives. Convenience, portability, and cost are the major reasons behind the success of mobile games (Bose \& Yang, 2011). On one hand, researchers tend to investigate the marketable avenues through which online mobile gamers can be delivered a value addition (Hofacker et al., 2016; Lin, 2014; Ström et al., 2014; Poels et al., 2013). On the other, research has investigated the psychological states of the online mobile game players (Yee, 2006; Cole \& Griffiths, 2007; Schwabe \& Göth, 2005; Phillips et al., 2006; Wei \& Lu, 2014). Electronic Entertainment Design and Research (EEDAR, 2014) reports that friends' recommendations, reviews, and top charts are the major considerations for a user to download a game. Unlike other online purchases, in-game purchases in mobile phones are more of an engaged output, which is dependent upon emotion, performance, and social value (Hsiao \& Chen, 2016). Initially, mobile games are offered freemium services but later users who wish to avail extra features and to buy virtual goods in the game pay for those actions (Staykova \& Damsgaard, 2015; Liu et al., 2015). In-game purchases require a long-term momentum within the game to motivate players to engage in such action, the more engagement and 'stickiness' towards the game the more it will enlarge the possibility of purchase action (Drell, 2013). In-game purchases may include: purchasing coins, extra lives, outfits, skipping stages, unlimited ammunition, etc. These in-game purchases can be of any benefit to the player during a high immersion or stickiness level with the game (Cleghorn \& Griffiths, 2015; Hsu \& Lin, 2016; Drell, 2013).

Previous literature has identified a number of strong determinants of online purchases including values (Keeney, 1999; Hsiao \& Chen, 2016; Hsu \& Lin, 2016), consumer experience (Elliot \& Fowell, 2000), consumer innovativeness (Varma Citrin et al., 2000), lifestyle (Swinyard \& Smith, 2003), security (Kwon and Lee, 2003), perceived risk (Doolin et al., 2007), information (Chemma \& Papatla, 2010), pricing (Weisstein et al., 2016), and subjective norms and behavioural control (George, 2002, 2004). From a psychological 
perspective, studies have also been carried out into online purchase behaviour in terms of impulsive and compulsive actions (Greenfield, 1999; Dittmar et al., 2007; Maraz et al., 2016). Unlike other online purchases, a mobile in-game purchase is a momentum-oriented action built upon quality bonding and high immersion (Hsu \& Lin, 2016). Despite many studies examining online game addiction (e.g., Griffiths 2010; Mehroof \& Griffiths 2010; Grüsser et al., 2007), limited attention has been given to specific online mobile game addiction and its consequences.

To the present authors' knowledge, only two previous studies have examined the relationship between online gaming and loyalty. Choi and Kim proposed a theoretical model comprising customer loyalty, flow, and social/personal interactions to explain why people repeatedly engage in online gaming via a survey of 1,993 gamers. Their results showed that habitual online gamers continue if they have optimal experiences (e.g., pleasant social interactions) while gaming. Lu and Wang (2008) explored the role that online game addiction plays in the association between online satisfaction and loyalty among 1,186 gamers. They reported that gaming addiction directly contributed to loyalty and attenuated the relationship between loyalty and satisfaction. They argued that their findings partially explained why players remain loyal to online games despite being dissatisfied.

Given the lack of research examining online gaming and loyalty, an in-depth study to understand the role of addiction and loyalty towards online mobile in-game purchase intention would contribute greatly to further research development in the field. Furthermore, filling this gap would provide robust data for industry experts and researchers to apply in their respective fields. Consequently, the present study attempts to examine the role of addiction and loyalty towards purchase intention. 


\section{Conceptual framework}

The conceptual framework of the present study is shown in Figure 1. The relationship between the constructs and hypothesis are described in the following sections.

\section{Online mobile game addiction and game loyalty}

Downloading a game is an initial action. However, experiential and appreciative gameplay develops a liking towards a game, and the liking later translates to an addiction state for a small minority. Previous studies have discussed addiction towards online games such as MMORPGs (Massively Multiplayer Online Role-Playing Games) (Cole \& Griffiths, 2007; Kuss \& Griffiths, 2012). Griffiths (2005) asserts that addictive behaviour comprises six core components (i.e., salience, tolerance, mood modification, relapse, withdrawal, conflict) and that these can be applied to online gaming in its most excessive form (Griffiths, 2010). Studies have also demonstrated that flow and addiction can increase the loyalty of game users (Khang et al., 2013; Lu \& Wang, 2008). Lu and Wang (2008) reported that long-term addictive actions can lead to loyalty. Some studies have addressed loyalty as an endogenous behaviour construct (Lee et al., 2015; Gu et al., 2016; Su et al., 2016 ), whereas other studies have addressed loyalty as a function that mediates purchase behaviour, word-of-mouth communication, user-generated content, and other important functions (Oliver, 1999). In the same context, research has investigated the role of addiction and its relationship with social seeking and peer attachment (Blinka \& Mikuska, 2014; Škařupová \& Blinka, 2016). Here, loyalty towards the game is the inherent reason for such action. Therefore, in the present study, it is proposed that online mobile game addiction can lead to loyalty towards the online mobile game.

H1: Online mobile game addiction will enhance online mobile game loyalty. 


\section{Intention to purchase online mobile in-game apps and features}

Many researchers have suggested a relationship between addiction state and purchase intention or activity (Wakefield et al., 2007; Duroy et al., 2014; Andreassen et al., 2015; Weinstein et al., 2016; Lee et al., 2016). However, there is limited empirical evidence in the context of online game addiction. Purchase intention is a rich action that requires both ability and motivation. The present study examines whether addiction and loyalty can both enhance purchase intention. While the relationship of mobile game addiction towards purchase intention is yet to be proved, the relationship between loyalty and purchase intention has strong empirical support. Numerous researchers have investigated the relationship with respect to different contexts. For instance, Dick and Basu (1994) asserted that most business activity is carried out with loyalty in mind. The more loyal the group, the less the new acquaintance costs which further brings in revenue (Semeijn et al., 2005). Loyalty combined with addiction can help establish a significant relationship with intention to purchase online mobile in-game apps.

$\mathrm{H} 2$ : Online mobile game addiction will enhance the intention to purchase online mobile ingame apps.

H3: Online mobile game loyalty will enhance the intention to purchase online mobile ingame apps.

$<$ Figure $1>$

\section{Methods}

\section{Participants and procedure}

The present study comprised 430 students from two major Indian universities. Previous studies have identified students as an appropriate target population for studies relating to 
mobile games (Ha et al., 2007; Okazaki, 2008). Despite mobile games gaining popularity and momentum across all age groups, students are always a welcoming customer considering their high level of engagement with videogames. The data for the present study was collected during a month-long period, from three workshops concerning 'Digital Tools and Advancements'. More specifically, the data were obtained after a session on 'MMORPGs and Business Models'. Participants of the survey were given a certificate for participating in the survey. A total of 470 respondents were chosen to participate given their active participation and knowledge in the MMORPG workshop. Of these, 430 completed the whole questionnaire. Earlier studies have supported using, minimum 100 to 200 sample (Boomsma, 1987), or at least 10 cases per variable (Nunnally, 1967) as a threshold criteria for testing structural equation modelling. The present study met the sample size requirements proposed by both Boomsma (1987) and Nunnally (1967)". The participants were almost equally distributed with regard to gender. The detailed sociodemographic characteristics of the total sample are presented in Table 1.

\section{Instruments and measures}

The questionnaire comprised 28 questions answered using a 5-point Likert scale wherein loyalty and purchase intention were assessed ( 5 being "strongly agree" and 1 being "strongly disagree"). One subscale assessing addiction also used a 5-point Likert scale (5 being "very often" and 1 being "never"). The questionnaire also comprised six categorical scale questions assessing sociodemographic characteristics of the sample. All measures (addiction, loyalty, and purchase intention) were derived from previous literature. The assessment of addiction was derived using Griffiths' (2005) components model (i.e., salience, tolerance, mood modification, relapse, withdrawal, and conflict). An additional component of 'problems' was also added. All the seven components of addiction comprised three items each. The scale for loyalty comprised two items derived from Choi and Kim (2004). Finally the scales for 
purchase intention comprised five items derived from various authors (i.e., Chu \& Lin, 2015; Chu \& Lin, 2016; Paul et al., 2016). The reliability and validity testing is discussed in the subsequent sections.

$<$ Table 1 $>$

\section{Analysis}

A two-step structural equation modelling with direct and indirect effects was performed to test the hypotheses. Initially a first-order confirmatory analysis was run to derive the factor score of addiction and also to test the validity and reliability of all the constructs under investigation. The analysis was performed using SPSS statistics 24 and Amos 19 graphics. Maximum likelihood model estimation was used in structural equation modelling. To check the direct and indirect effect, the factor scores of addiction, loyalty, and purchase were imputed and the scores were used to check the final model. Furthermore, bootstrapping was used to further test the indirect effect significance (Preacher \& Hayes, 2008). The bootstrap was performed with 5000 resamples estimated using a 95\% confidence interval. An analysis of variance (ANOVA) was conducted to examine the mean difference among the variables with reference to male and female respondents. The results of ANOVA were compared using the effect size (Eta Square) of the model, which explains the variance of the sample in total for all constructs (Kotrlik and Williams, 2003). Multiple comparisons were corrected using Bonferroni pairwise comparison test to reduce the effect of type I error (Keppel \& Wickens, 2004). Multivariate analysis of variance (MANOVA) was used to examine the overall variance difference of the seven sub-components of addiction. This was carried out to examine the difference in addiction levels between male and female respondents. 


\section{Results}

Both confirmatory and structural model exhibited good model fit indices. The estimates and effects indicated meaningful results. All three hypotheses were significantly confirmed.

$<$ Table 2>

\section{Measurement model - Confirmatory Factor Analysis (CFA)}

Table 2 provides the detailed values of each construct and items. The reliability of all the constructs was above 0.70 , which confirms the scales are free from measurement error (Portney and Watkins, 2000). All items in the model exhibited a value more than 0.60 with significance at the $99 \%$ level. This fulfils the content validity requirement for the CFA. The Average Variance Extracted (AVE) score for the constructs were observed to be more than 0.50 , which further satisfies the requirement for convergent validity. The $\sqrt{ }$ AVE score and the squared inter-correlation values are shown in Table 3. The $\sqrt{ }$ AVE score for purchase intention and loyalty was higher than their respective squared inter-correlation values, and therefore satisfies the discriminant validity requirements. The remaining sub-components established high correlation values between them. This is to be expected considering they belong to the same latent construct. All validity requirements met the expectation proposed by Bagozzi et al. (1991), and Fornell and Larcker (1981). The measurement model exhibited a good fit (see Table 2). All sub-components of addiction provided first order loadings above 0.60: salience (0.998, $p<0.001)$, tolerance $(0.948, p<0.001)$, mood modification $(0.939, p<0.001)$, relapse (0.797, $p<0.001)$, problems $(0.779, p<0.001)$, conflict $(0.706, p<0.001)$, and withdrawal $(0.678, p<0.001)$.

$<$ Table 3> 


\section{Structural model - Hypothetical model}

The total effects model demonstrated a good fit which further allows us to validate the results of the hypotheses. The fit indices are shown in Table 4. All hypotheses from H1 to H3 were supported. Table 4 exhibits the total effect values for the proposed hypothetical model, in which the path between addiction and loyalty was found to have high significant relationship (Hypothesis $1 ; \beta=0.727 ; p<0.001$ ). It was also observed that loyalty exhibited a higher significant value towards purchase intention (Hypothesis $3 ; \beta=0.459 ; p<0.001$ ) than addiction (Hypothesis $2 ; \beta=0.341 ; p<0.001)$. The $\mathrm{r}^{2}$ value for loyalty $\left(\mathrm{r}^{2}=0.530\right)$ was observed to be higher than purchase intention $\left(r^{2}=0.270\right)$ which also signifies the relationship that addiction and loyalty share. The direct and indirect effect of loyalty for the path, addiction towards purchase intention was calculated. It was observed that the indirect effect of the path $(\beta=0.348 ; p<0.001)$ was higher than that of the direct path relationship between addiction and purchase intention $(\beta=0.212 ; p<0.001)$.

The ANOVA results and factor mean values are presented in Table 6. The results show that all the nine factors; salience, tolerance, mood modification, relapse, withdrawal, conflict, problems, purchase intention, and loyalty extracted a significant mean difference among male and female respondents $(\mathrm{p}<0.0001)$. When the Bonferroni correction factor was introduced in the ANOVA, the results remained same. The model $r^{2}$ ranged from 0.356 to 0.398 across all the nine factors. The effect sizes of the nine factors (see eta square values in Table 6) indicated that salience explained the most variance in the model $(\eta 2=0.399)$. All the components explained a variance above 0.250 except for purchase intention which explained the least variance $(\eta 2=0.077)$ in the complete model. Findings from the MANOVA indicated that the total variance difference of the seven factors differed across male and female respondents $(\lambda=0.536 ; \mathrm{f}=52.186 ; p<0.0001)$. Moreover, males were identified as having higher mean scores on all the factors. To explore this further, chi-squared tests 
between male and female participants with respect to average time spent playing online mobile games $\left(\chi^{2}=8.452 ; \mathrm{df}=4 ; p=0.076\right)$ and number of in-app purchases $\left(\chi^{2}=1.778 ; \mathrm{df}=3\right.$; $p=0.620$ ) were carried out. The results demonstrated there were no significant gender differences male and female respondents, which further validated the results of the ANOVA and implies that the level of addiction significantly differed between male and female respondents.

$<$ Tables 4 to $6>$

\section{Discussion}

The present study investigated the triangular model between three variables (i.e., addiction, loyalty towards online games, and purchase intention towards online mobile in-game apps). The model examines the total effect between the three variables, the direct effect between addiction and purchase intention, and the indirect effect between addiction and purchase intention, with loyalty as a mediator. The total effects model supported all three hypotheses in that (i) online mobile game addiction enhance online mobile game loyalty, (ii) online mobile game addiction enhanced the intention to purchase online mobile in-game apps, and (iii) online mobile game loyalty enhanced the intention to purchase online mobile in-game apps. Furthermore, it was also observed that loyalty was a strong mediator which resulted in a high indirect effect rather than a direct effect between loyalty and purchase intention.

\section{Addiction and purchase intention}

Earlier studies have extensively discussed online gaming addiction state and its psychological consequences. The present study explored a new dimension, namely the role of addiction towards purchase intention and found that addiction increases the likelihood of purchase intention. Purchase intention is a commercial state through which marketers understand consumers for any further development. The era of digital games is gaining momentum. 
Unlike other digital platforms, online mobile games are gaining attention equally among the developers and researchers. Online gaming addiction is an extreme behaviour which can trigger the users to many further consequences. The present study demonstrated that addiction has the capacity to stimulate the users' intention to purchase in-game apps. There is of course a conflict for the game developers between being socially responsible and increasing profits. Furthermore, scholars are attempting to understand and prevent online gaming addiction, whereas marketers and game developers are attempting to design financially lucrative features that will immerse users within the game and make them spend more money. The present research provides insights on both these perspectives.

The mean values of the addiction sub-components were more than 3 (out of 5), which suggests a higher than average prevalence of gaming addiction among the male respondents. Further analysis demonstrated that that purchase intention did not differ $(\mathrm{F}=1.150 ; \mathrm{df}=3,426$; $p=0.329)$ across the categories concerning in-app purchases made during the past year. The results of all seven sub-components of addiction were higher among males than compared to females. Similarly, male respondents indicated a higher intention to purchase mobile in-game apps when compared to females. This is an additional important insight for researchers and game developers. Future research can focus more on investigating the male population in understanding the engrossing and immersive nature of online mobile games. The results of the present study also suggest game developers will target their marketing and behavioural tracking more specifically with males to increase their conversion funnel to convert more ingame purchases. The results can be rationally validated. For example, previous studies have found 'stickiness' towards a game can enhance the purchase intention of apps (Hsu and Lin, 2015; Hsu and Lin, 2016). The findings of the present study are a novel addition to both the psychological and business management research literature.

\section{Role of loyalty}


The mean values of loyalty in the present study were more than the average scale value, and male respondents had relatively higher loyalty scores than females. Loyalty is a very important construct from a marketing perspective, because loyalty can lead to positive word of mouth spread and repeat purchases. The study here investigated loyalty as a mediator between addiction and purchase intention. The results indicated a high indirect effect presence due to mediator presence, and emphasises the important role of loyalty towards the game. In marketing terms, customers start as an initiator and later down the funnel they become a loyal agent for any product or service. As the results here imply, converting online mobile game users' to loyal customers is a mandatory action to instil purchase intention among them. Results in the present study suggest addiction can strongly stimulate purchase intention among users that are more loyal towards the game. Loyalty gradually grows when there is a long-term association with the game, and users may feel comfortable for being loyal and supporting online games (Choi \& Kim, 2004). Loyalty can motivate users' to write reviews, rate the games, spread good things by word of mouth, etc. (i.e., more conscious actions that users can perform). Game developers and marketers should attempt various methods to create loyalty among the users but getting players 'addicted' should not be the way to do it.

Psychological research has extensively discussed gaming addiction and its consequences, but the present research is arguably the first study to relate loyalty and gaming addiction in relation to the purchase of in-game apps. Addiction and loyalty share a significant relationship and emphasises that addiction may also stimulate loyalty. This is an important finding for psychological research, and may help stimulate future research in further understanding addiction via loyalty. Loyalty is a dynamic phenomenon which traditionally is built upon rational thinking and conscious following of the games, whereas addiction - while a dynamic phenomenon - is often built upon irrationality and unconscious repetitive 
behaviour. It is recommended that future research explores the relationship between loyalty and addiction in different contexts, especially it would appear to be especially fruitful to further understand direct or indirect consequences of addiction in relation to purchasing behaviour in the gaming context.

The present study empirically demonstrated a relationship between addiction and purchase intention - at least among the participants studied here. There are of course a number of limitations, including the fact that the sample was self-selected and the data are self-report (subject to many well-known biases). Given the relatively young age of the sample and comprised only students, along with the fact that approximately half of the sample were casual players (playing less than an hour a day), the generalizability of the findings need to be interpreted with some caution. The study needs replicating using a more representative population with more widespread gaming frequency. Despite these limitations, the research identified that loyalty can be an effective mediator between addiction and purchase intention.

The results will be useful in framing psychological models and may act as an important variable for game developers to think about. Game developers will always want to facilitate loyalty among its clientele. However, if the engagement strategies used by the gaming operators facilitate addiction as a way of increasing purchase intention of online mobile game in-game apps, this raises serious ethical questions which the gaming industry need to address as part of its corporate social responsibility strategy and which has been discussed at length by other scholars (van Rooij, Meerkerk, Schoenmakers et al., 2010; Yousafzai, Hussain \& Griffiths, 2014). The study employed three main constructs (addiction, loyalty, and purchase intention), and future research may want to examine different variables to develop more robust models of how purchase intentions can be facilitated and stimulated by game developers and marketers more generally. Moreover, the study results may motivate marketers to try creating an addiction level among the gamers, which raises serious ethical 
issues, future frameworks can address this issue with a strong balance ethical balance in the model.

\section{References}

Alha, K., Koskinen, E., Paavilainen, J., \& Hamari, J. (2016). Critical acclaim and commercial success in mobile free-to-play games. Proceedings of DiGRA FDG Conference (pp. 1-6). Dundee, Scotland: DIGRA.

Andreassen, C. S., Griffiths, M. D., Pallesen, S., Bilder, R. M., Torsheim, T., \& Aboujaoude, E. (2015). The Bergen Shopping Addiction Scale: Reliability and validity of a brief screening test. Frontiers in Psychology, 6, 1374. doi: 10.3389/fpsyg.2015.01374.

Android Authority (2016). 2016 recap: 90\% of Google Play's revenue came from games (and more fun stats!). Retrieved January 4, 2018, from: http://www.androidauthority.com/2016-recap-90-percent-google-play-revenue-gaming-fun$\underline{\text { stats-743626/ }}$

Bagozzi, R. P., Yi, Y., \& Phillips, L. W. (1991). Assessing construct validity in organizational research. Administrative Science Quarterly, 36(3), 421-458.

Blinka, L., \& Mikuška, J. (2014). The role of social motivation and sociability of gamers in online game addiction. Cyberpsychology: Journal of Psychosocial Research on Cyberspace, 8(2). Retrieved January 4, 2018, from: https://cyberpsychology.eu/article/view/4309/3358 
Boomsma, A. (1987). The robustness of maximum likelihood estimation in structural equation models. In Cuttance, P. \& Ecob, R. (Eds.), Structural equation modeling by example (pp. 160-188). New York: Cambridge University Press.

Bose, I., \& Yang, X. (2011). Enter the dragon: Khillwar's foray into the mobile gaming market of China. Communications of the Association for Information Systems, 29, 551-564

Cheema, A., \& Papatla, P. (2010). Relative importance of online versus offline information for Internet purchases: Product category and Internet experience effects. Journal of Business Research, 63(9), 979-985.

Choi, D., \& Kim, J. (2004). Why people continue to play online games: In search of critical design factors to increase customer loyalty to online contents. CyberPsychology \& Behavior, 7(1), 11-24.

Cleghorn, J., \& Griffiths, M. D. (2015). Why do gamers buy 'virtual assets'? An insight in to the psychology behind purchase behaviour. Digital Education Review, 27, 85-104.

Cole, H., \& Griffiths, M. D. (2007). Social interactions in massively multiplayer online roleplaying gamers. CyberPsychology \& Behavior, 10(4), 575-583.

Dick, A. S., \& Basu, K. (1994). Customer loyalty: Toward an integrated conceptual framework. Journal of the Academy of Marketing Science, 22(2), 99-113. 
Dittmar, H., Long, K., \& Bond, R. (2007). When a better self is only a button click away: Associations between materialistic values, emotional and identity-related buying motives, and compulsive buying tendency online. Journal of Social and Clinical Psychology, 26(3), 334-361.

Doolin, B., Dillons, S., Thompson, F., \& Corner, J. L. (2007). Perceived risk, the Internet shopping experience and online purchasing behavior: A New Zealand perspective. Electronic commerce: Concepts, methodologies, tools, and applications, 324-345.

Drell. L (2013). 9 mobile app KPIs to know. Mashable.com. Retrieved January 4, 2018, from: http://mashable.com/2013/09/04/mobile-app-metrics/\#R8zqxYBQQmqy

Duroy, D., Gorse, P., \& Lejoyeux, M. (2014). Characteristics of online compulsive buying in Parisian students. Addictive Behaviors, 39(12), 1827-1830.

Electronic Entertainment Design and Research (2014). Deconstructing mobile \& tablet Gaming. EEDAR's Annual Report. Retrieved January 4, 2018, from: http://www.eedar.com/sites/default/files/EEDAR\%20-Mobile\%20Report\%202016\%20\%20Whitepaper.pdf

Elliot, S., \& Fowell, S. (2000). Expectations versus reality: a snapshot of consumer experiences with Internet retailing. International Journal of Information Management, 20(5), 323-336. 
Fornell, C., \& Larcker, D. F. (1981). Evaluating structural equation models with unobservable variables and measurement error. Journal of Marketing Research, 18(4), 39-50.

Gainsbury, S. M., King, D. L., Russell, A. M., \& Delfabbro, P. (2016). Who pays to play freemium games? The profiles and motivations of players who make purchases within social casino games. Journal of Behavioral Addictions, 5(2), 221-230.

George, J. F. (2002). Influences on the intent to make Internet purchases. Internet Research, 12(2), 165-180.

George, J. F. (2004). The theory of planned behavior and Internet purchasing. Internet Research, 14(3), 198-212.

Greenfield, D. N. (1999). Psychological characteristics of compulsive Internet use: A preliminary analysis. CyberPsychology \& Behavior, 2(5), 403-412.

Griffiths, M. D. (2010). The role of context in online gaming excess and addiction: Some case study evidence. International Journal of Mental Health and Addiction, 8(1), 119-125.

Griffiths, M. D. (2005). A 'components' model of addiction within a biopsychosocial framework. Journal of Substance Use, 10(4), 191-197.

Grüsser, S. M., Thalemann, R., \& Griffiths, M. D. (2006). Excessive computer game playing: evidence for addiction and aggression?. CyberPsychology \& Behavior, 10(2), 290-292. 
Gu, R., Oh, L. B., \& Wang, K. (2016). Developing user loyalty for social networking sites: a relational perspective. Journal of Electronic Commerce Research, 17(1), Paper 1.

Ha, I., Yoon, Y., \& Choi, M. (2007). Determinants of adoption of mobile games under mobile broadband wireless access environment. Information \& Management, 44(3), 276-286.

Hofacker, C. F., De Ruyter, K., Lurie, N. H., Manchanda, P., \& Donaldson, J. (2016). Gamification and mobile marketing effectiveness. Journal of Interactive Marketing, 34, 2536.

Hsiao, K. L., \& Chen, C. C. (2016). What drives in-app purchase intention for mobile games? An examination of perceived values and loyalty. Electronic Commerce Research and Applications, 16, 18-29.

Hsu, C. L., \& Lin, J. C. C. (2015). What drives purchase intention for paid mobile apps?-An expectation confirmation model with perceived value. Electronic Commerce Research and Applications, 14(1), 46-57.

Hsu, C. L., \& Lin, J. C. C. (2016). Effect of perceived value and social influences on mobile app stickiness and in-app purchase intention. Technological Forecasting and Social Change, 108, 42-53.

Keeney, R. L. (1999). The value of Internet commerce to the customer. Management Science, 45(4), 533-542. 
Keppel, G., \& Wickens, T. D. (2004). Simultaneous comparisons and the control of type I errors. Design and analysis: A researcher's handbook (4th ed.) (pp.111-130). Upper Saddle River, NJ: Pearson Prentice Hall.

Khang, H., Kim, J. K., \& Kim, Y. (2013). Self-traits and motivations as antecedents of digital media flow and addiction: The Internet, mobile phones, and video games. Computers in Human Behavior, 29(6), 2416-2424.

Kotrlik, J. W., \& Williams, H. A. (2003). The incorporation of effect size in information technology, learning, and performance research. Information Technology, Learning, and Performance Journal, 21(1), 1-7.

Kuss, D. J., \& Griffiths, M. D. (2012). Internet gaming addiction: A systematic review of empirical research. International Journal of Mental Health and Addiction, 10(2), 278-296.

Kwon, K. N., \& Lee, J. (2003). Concerns about payment security of Internet purchases: a perspective on current on-line shoppers. Clothing and Textiles Research Journal, 21(4), 174184.

Lee, D., Moon, J., Kim, Y. J., \& Mun, Y. Y. (2015). Antecedents and consequences of mobile phone usability: Linking simplicity and interactivity to satisfaction, trust, and brand loyalty. Information \& Management, 52(3), 295-304.

Lee, S., Park, J., \& Bryan Lee, S. (2016). The interplay of Internet addiction and compulsive shopping behaviors. Social Behavior and Personality, 44(11), 1901-1912. 
Leppaniemi, M., \& Karjaluoto, H. (2005). Factors influencing consumers' willingness to accept mobile advertising: a conceptual model. International Journal of Mobile Communications, 3(3), 197-213.

Lin, H. F. (2014). The effect of product placement on persuasion for mobile phone games. International Journal of Advertising, 33(1), 37-60.

Liu, J., Kauffman, R. J., \& Ma, D. (2015). Competition, cooperation, and regulation: Understanding the evolution of the mobile payments technology ecosystem. Electronic Commerce Research and Applications, 14(5), 372-391.

Lu, H. P., \& Wang, S. M. (2008). The role of Internet addiction in online game loyalty: an exploratory study. Internet Research, 18(5), 499-519.

Maraz, A., Griffiths, M. D., \& Demetrovics, Z. (2016). The prevalence of compulsive buying: A meta-analysis. Addiction, 111(3), 408-419.

Mehroof, M., \& Griffiths, M. D. (2010). Online gaming addiction: the role of sensation seeking, self-control, neuroticism, aggression, state anxiety, and trait anxiety. Cyberpsychology, Behavior, and Social Networking, 13(3), 313-316.

Nunnally JC. (1967). Psychometric theory. New York, NY: McGraw-Hill.

Tsang, M. M., Ho, S. C., \& Liang, T. P. (2004). Consumer attitudes toward mobile advertising: An empirical study. International Journal of Electronic Commerce, 8(3), 65-78. 
Okazaki, S. (2008). Exploring experiential value in online mobile gaming adoption. CyberPsychology \& Behavior, 11(5), 619-622.

Oliver, R. L. (1999). Whence consumer loyalty? Journal of Marketing, 63, 33-44.

Paul, J., Modi, A., \& Patel, J. (2016). Predicting green product consumption using theory of planned behavior and reasoned action. Journal of Retailing and Consumer Services, 29, 123134.

Phillips, J. G., Butt, S., \& Blaszczynski, A. (2006). Personality and self-reported use of mobile phones for games. CyberPsychology \& Behavior, 9(6), 753-758.

Poels, K., Janssens, W., \& Herrewijn, L. (2013). Play buddies or space invaders? Players' attitudes toward in-game advertising. Journal of Advertising, 42(2-3), 204-218.

Portney, L. G., \& Watkins, M. P. (2000). Foundations of clinical research: Applications to practice. Upper Saddle River: Prentice Hall Health.

Preacher, K. J., \& Hayes, A. F. (2008). Asymptotic and resampling strategies for assessing and comparing indirect effects in multiple mediator models. Behavior Research Methods, 40(3), 879-891. 
Rajala, R., Rossi, M., Tuunainen, V. K., \& Vihinen, J. (2007). Revenue logics of mobile entertainment software observations from companies producing mobile games. Journal of Theoretical and Applied Electronic Commerce Research, 2(2), 34-47.

Schwabe, G., \& Göth, C. (2005). Mobile learning with a mobile game: design and motivational effects. Journal of Computer Assisted Learning, 21(3), 204-216.

Semeijn, J., van Riel, A. C., van Birgelen, M. J., \& Streukens, S. (2005). E-services and offline fulfilment: how e-loyalty is created. Managing Service Quality: An International Journal, 15(2), 182-194.

Škařupová, K., \& Blinka, L. (2015). Interpersonal dependency and online gaming addiction. Journal of Behavioral Addictions, 5(1), 108-114.

Statistica (2016). Worldwide mobile app store revenues in 2015, 2016 and 2020 (in billion U.S. dollars). Retrieved January 4, 2018, from: https://www.statista.com/statistics/220186/total-global-in-app-revenue-forecast/

Staykova, K. S., \& Damsgaard, J. (2015). The race to dominate the mobile payments platform: Entry and expansion strategies. Electronic Commerce Research and Applications, 14(5), 319-330.

Ström, R., Vendel, M., \& Bredican, J. (2014). Mobile marketing: A literature review on its value for consumers and retailers. Journal of Retailing and Consumer Services, 21(6), 10011012. 
Su, Y. S., Chiang, W. L., Lee, C. T. J., \& Chang, H. C. (2016). The effect of flow experience on player loyalty in mobile game application. Computers in Human Behavior, 63, 240-248.

Swinyard, W. R., \& Smith, S. M. (2003). Why people (don't) shop online: A lifestyle study of the internet consumer. Psychology \& Marketing, 20(7), 567-597.

van Rooij, A, J., Meerkerk, G. Schoenmakers, T.M., Griffiths, M. D., \& van de Mheen, D. (2010). Video game addiction and social responsibility, Addiction Research and Theory, 18, 489-493.

Varma Citrin, A. V., Sprott, D. E., Silverman, S. N., \& Stem Jr, D. E. (2000). Adoption of Internet shopping: the role of consumer innovativeness. Industrial Management \& Data Systems, 100(7), 294-300.

Wakefield, M., Germain, D., \& Henriksen, L. (2008). The effect of retail cigarette pack displays on impulse purchase. Addiction, 103(2), 322-328.

Wei, P. S., \& Lu, H. P. (2014). Why do people play mobile social games? An examination of network externalities and of uses and gratifications. Internet Research, 24(3), 313-331.

Weinstein, A., Maraz, A., Griffiths, M. D., Lejoyeux, M., \& Demetrovics, Z. (2016). Compulsive buying - Features and characteristics of addiction. In Preedy, V. (Ed.), The Neuropathology Of Drug Addictions And Substance Misuse (Vol. 3). (pp. 993-1008). London: Academic Press. 
Weisstein, F. L., Kukar-Kinney, M., \& Monroe, K. B. (2016). Determinants of consumers' response to pay-what-you-want pricing strategy on the Internet. Journal of Business Research, 69(10), 4313-4320.

West, J. H., Hall, P. C., Hanson, C. L., Barnes, M. D., Giraud-Carrier, C., \& Barrett, J. (2012). There's an app for that: Content analysis of paid health and fitness apps. Journal of Medical Internet Research, 14(3), e72.

Willson, M., \& Leaver, T. (2017). Social, casual and mobile games: The changing gaming landscape. New York: Bloomsbury Publishing.

Yee, N. (2006). Motivations for play in online games. CyberPsychology \& Behavior, 9(6), $772-775$.

Yousafzai, S. Y., Hussain, Z., \& Griffiths, M. D. (2014). Social responsibility in online videogaming: What should the videogame industry do? Addiction Research and Theory, 22, $181-185$. 


\section{List of Tables:}

Table 1: Demographic characteristics of the sample

Table 2: Measurement model for the observed variables

Table 3: Inter construct correlation table with $\sqrt{ } A V E$ scores

Table 4: Total effects for the proposed model

Table 5: Direct and Indirect effects for endogenous variables

Table 6: ANOVA for male and female respondents 


\begin{tabular}{|c|c|c|c|}
\hline \multicolumn{4}{|c|}{ Table 1: Demographic characteristics of the sample $(N=430)$} \\
\hline \multicolumn{2}{|c|}{ Characteristics } & Frequency & $\%$ \\
\hline \multirow[t]{2}{*}{ Gender } & Male & 217 & 50.46 \\
\hline & Female & 213 & 49.54 \\
\hline \multirow[t]{3}{*}{ Education } & Undergraduate & 166 & 38.60 \\
\hline & Postgraduate & 226 & 52.56 \\
\hline & Fellow/PhD/Doctoral & 38 & 8.84 \\
\hline \multirow[t]{4}{*}{ Age } & 16 to 20 years & 156 & 36.28 \\
\hline & 21 to 25 years & 130 & 30.23 \\
\hline & 26 to 30 years & 112 & 26.05 \\
\hline & Above 30 years & 32 & 7.44 \\
\hline \multirow{9}{*}{$\begin{array}{l}\text { Favourite game } \\
\text { category }\end{array}$} & Action & 48 & 11.16 \\
\hline & Adventure & 38 & 8.84 \\
\hline & Card & 36 & 8.37 \\
\hline & Puzzle & 52 & 12.09 \\
\hline & Racing & 61 & 14.19 \\
\hline & Role Playing & 51 & 11.86 \\
\hline & Sports & 103 & 23.95 \\
\hline & Strategy & 33 & 7.67 \\
\hline & Simulation & 8 & 1.86 \\
\hline \multirow{5}{*}{$\begin{array}{l}\text { Average time } \\
\text { spent on } \\
\text { game/day }\end{array}$} & More than 120 minutes & 56 & 13.02 \\
\hline & 90 to 120 minutes & 72 & 16.74 \\
\hline & 60 to 89 minutes & 98 & 22.79 \\
\hline & 30 to 59 minutes & 147 & 33.95 \\
\hline & Less than 30 minutes & 57 & 13.49 \\
\hline \multirow{4}{*}{$\begin{array}{l}\text { Number of In- } \\
\text { app purchases } \\
\text { made during the } \\
\text { past year }\end{array}$} & Above 10 purchases & 56 & 13.02 \\
\hline & 5 to 10 purchases & 72 & 16.74 \\
\hline & 1 to 5 purchases & 91 & 21.16 \\
\hline & None during the last year & 211 & 49.07 \\
\hline
\end{tabular}




\begin{tabular}{|c|c|c|c|c|}
\hline \multicolumn{5}{|c|}{ Table 2: Measurement model for the observed variables } \\
\hline Construct & Items & $\begin{array}{l}\text { Mean (Std Dev) } \\
\mathbf{N}=\mathbf{4 3 0}\end{array}$ & $\begin{array}{l}\text { Factor } \\
\text { loadings }\end{array}$ & $\begin{array}{l}\text { AVE and Composite } \\
\text { Reliability }\end{array}$ \\
\hline \multirow{3}{*}{ Salience } & Salience 1 & $3.42(0.864)$ & $0.761^{* * *}$ & \multirow{3}{*}{$\begin{array}{c}\mathrm{AVE}=0.549 \\
\mathrm{CR}=0.789\end{array}$} \\
\hline & Salience 2 & $3.42(0.954)$ & $0.755^{* * *}$ & \\
\hline & Salience 3 & $3.37(0.941)$ & $0.705^{* * *}$ & \\
\hline \multirow{3}{*}{ Tolerance } & Tolerance 1 & $3.40(0.935)$ & $0.745^{* * *}$ & \multirow{3}{*}{$\begin{array}{c}\mathrm{AVE}=0.588 \\
\mathrm{CR}=0.811\end{array}$} \\
\hline & Tolerance 2 & $3.34(1.000)$ & $0.769^{* * *}$ & \\
\hline & Tolerance 3 & $3.33(0.945)$ & $0.786^{* * *}$ & \\
\hline \multirow{3}{*}{ Mood Modification } & Mood Modification 1 & $3.41(0.850)$ & $0.729^{* * *}$ & \multirow{3}{*}{$\begin{array}{c}\mathrm{AVE}=0.627 \\
\mathrm{CR}=0.835\end{array}$} \\
\hline & Mood Modification 2 & $3.39(0.919)$ & $0.765^{* * *}$ & \\
\hline & Mood Modification 3 & $3.43(0.895)$ & $0.794^{* * *}$ & \\
\hline \multirow{3}{*}{ Relapse } & Relapse 1 & $3.34(1.020)$ & $0.747^{* * *}$ & \multirow{3}{*}{$\begin{array}{c}\mathrm{AVE}=0.529 \\
\mathrm{CR}=0.771\end{array}$} \\
\hline & Relapse 2 & $3.25(1.083)$ & $0.727^{* * *}$ & \\
\hline & Relapse 3 & $3.47(1.095)$ & $0.708^{* * *}$ & \\
\hline \multirow{3}{*}{ Withdrawal } & Withdrawal 1 & $3.27(1.015)$ & $0.692^{* * *}$ & \multirow{3}{*}{$\begin{array}{c}\mathrm{AVE}=0.535 \\
\mathrm{CR}=0.775\end{array}$} \\
\hline & Withdrawal 2 & $3.26(1.065)$ & $0.792^{* * *}$ & \\
\hline & Withdrawal 3 & $3.24(1.147)$ & $0.708^{* * *}$ & \\
\hline \multirow{3}{*}{ Conflict } & Conflict 1 & $3.09(1.188)$ & $0.693^{* * * *}$ & \multirow{3}{*}{$\begin{aligned} \mathrm{AVE} & =0.513 \\
\mathrm{CR} & =0.759\end{aligned}$} \\
\hline & Conflict 2 & $3.04(1.127)$ & $0.736^{* * *}$ & \\
\hline & Conflict 3 & $2.96(1.226)$ & $0.718^{* * *}$ & \\
\hline \multirow{3}{*}{ Problems } & Problems 1 & $3.56(1.023)$ & $0.692^{* * *}$ & \multirow{3}{*}{$\begin{aligned} \mathrm{AVE} & =0.612 \\
\mathrm{CR} & =0.825\end{aligned}$} \\
\hline & Problems 2 & $3.60(0.968)$ & $0.648^{* * * *}$ & \\
\hline & Problems 3 & $3.63(0.991)$ & $0.734^{* * *}$ & \\
\hline \multirow{5}{*}{$\begin{array}{l}\text { Purchase Intention of } \\
\text { Mobile In-app } \\
\text { purchases }\end{array}$} & Purchase Intention 1 & $3.43(0.931)$ & $0.805^{* * *}$ & \multirow{5}{*}{$\begin{array}{c}\mathrm{AVE}=0.694 \\
\mathrm{CR}=0.918\end{array}$} \\
\hline & Purchase Intention 2 & $3.44(0.882)$ & $0.719^{* * *}$ & \\
\hline & Purchase Intention 3 & $3.53(1.085)$ & $0.923^{* * *}$ & \\
\hline & Purchase Intention 4 & $3.38(0.827)$ & $0.743^{* * *}$ & \\
\hline & Purchase Intention 5 & $3.52(1.085)$ & $0.938^{* * *}$ & \\
\hline \multirow{2}{*}{$\begin{array}{l}\text { Loyalty towards online } \\
\text { mobile games }\end{array}$} & Loyalty 1 & $3.46(0.881)$ & $0.769^{* * *}$ & \multirow{2}{*}{$\begin{array}{c}\mathrm{AVE}=0.579 \\
\mathrm{CR}=0.734\end{array}$} \\
\hline & Loyalty 2 & $3.53(0.867)$ & $0.753^{* * *}$ & \\
\hline lel Fit Indices: $c n$ & $\begin{array}{l}=2.314 ; G F I=0 . \\
\text { at at } 99 \% \text { confidenc }\end{array}$ & $F I=0.942 ; N$ & $.903 ; R M$ & 055 \\
\hline
\end{tabular}




\begin{tabular}{|l|l|l|l|l|l|l|l|l|l|}
\hline \multicolumn{7}{|c|}{ Table 3: Inter construct correlation table with $\sqrt{\boldsymbol{A} \text { VE scores }}$} \\
\hline & PI & SL & MM & RE & WL & CF & TC & PS & LY \\
\hline Purchase Intention (PI) & $\mathbf{0 . 8 3 3}$ & & & & & & & & \\
\hline Salience (SL) & 0.368 & $\mathbf{0 . 7 4 0}$ & & & & & & & \\
\hline Mood Modification (MM) & 0.371 & 0.964 & $\mathbf{0 . 7 9 2}$ & & & & & & \\
\hline Relapse(RE) & 0.519 & 0.749 & 0.748 & $\mathbf{0 . 7 2 8}$ & & & & & \\
\hline Withdrawal (WL) & 0.365 & 0.612 & 0.572 & 0.702 & $\mathbf{0 . 7 3 1}$ & & & & \\
\hline Conflict (CF) & 0.350 & 0.637 & 0.636 & 0.698 & 0.780 & $\mathbf{0 . 7 1 6}$ & & & \\
\hline Tolerance (TC) & 0.359 & 0.998 & 0.907 & 0.689 & 0.595 & 0.619 & $\mathbf{0 . 7 6 7}$ & & \\
\hline Problems (PS) & 0.614 & 0.749 & 0.709 & 0.930 & 0.711 & 0.595 & 0.689 & $\mathbf{0 . 7 8 3}$ & \\
\hline Loyalty (LY) & 0.428 & 0.606 & 0.561 & 0.577 & 0.507 & 0.559 & 0.559 & 0.598 & $\mathbf{0 . 7 6 1}$ \\
\hline The diagonal values represent $\sqrt{\boldsymbol{A V E}}$ & & & & & & \\
\hline
\end{tabular}




\begin{tabular}{|c|c|c|c|c|c|}
\hline \multicolumn{6}{|c|}{ Table 4: Total effects for the proposed model } \\
\hline \multirow{2}{*}{$\begin{array}{c}\text { Endogenous } \\
\text { factor } \\
\text { (Dependent) }\end{array}$} & \multirow[t]{2}{*}{$\begin{array}{l}\text { Exogenous factor } \\
\text { (Independent) }\end{array}$} & \multirow[t]{2}{*}{ Estimate } & \multirow[t]{2}{*}{$r^{2}$} & \multicolumn{2}{|c|}{$\begin{array}{c}\text { Bootstrap values at } \\
\text { confidence interval at } 95 \%\end{array}$} \\
\hline & & & & $\begin{array}{l}\text { Upper } \\
\text { bound }\end{array}$ & $\begin{array}{l}\text { Lower } \\
\text { bound }\end{array}$ \\
\hline \multirow{2}{*}{$\begin{array}{l}\text { Intention to } \\
\text { purchase the } \\
\text { online mobile } \\
\text { game in-app } \\
\text { features }\end{array}$} & $\begin{array}{l}\text { Loyalty towards online } \\
\text { mobile games (H3) }\end{array}$ & $0.459^{* * *}$ & \multirow[b]{2}{*}{0.270} & 0.473 & 0.195 \\
\hline & $\begin{array}{l}\text { Addiction towards online } \\
\text { mobile games (H2) }\end{array}$ & $0.341^{* * *}$ & & 0.551 & 0.363 \\
\hline Loyalty & $\begin{array}{l}\text { Addiction towards online } \\
\text { mobile games }(\mathrm{H} 1)\end{array}$ & $0.727^{* * *}$ & 0.530 & 0.777 & 0.670 \\
\hline \multicolumn{6}{|c|}{$\begin{array}{l}\text { Bootstrap: } 5000 \text { samples at } 95 \% \text { confidence level } \\
* * * \\
\text { represents significant at } 95 \% \text { confidence level }\end{array}$} \\
\hline
\end{tabular}




\begin{tabular}{|c|c|c|c|c|c|}
\hline \multicolumn{6}{|c|}{ Table 5: Direct and Indirect effects for endogenous variables } \\
\hline \multirow{2}{*}{$\begin{array}{l}\text { Endogenous } \\
\text { factor } \\
\text { (Dependent) }\end{array}$} & \multirow[t]{2}{*}{$\begin{array}{l}\text { Exogenous factor } \\
\text { (Independent) }\end{array}$} & \multirow[t]{2}{*}{$\begin{array}{c}\text { Estimates } \\
\text { (effect) }\end{array}$} & \multirow[t]{2}{*}{ S.E } & \multicolumn{2}{|c|}{$\begin{array}{c}\text { Bootstrap values at } \\
\text { confidence interval at } 95 \%\end{array}$} \\
\hline & & & & $\begin{array}{l}\text { Upper } \\
\text { bound }\end{array}$ & $\begin{array}{l}\text { Lower } \\
\text { bound }\end{array}$ \\
\hline \multicolumn{6}{|c|}{ Direct effects model } \\
\hline $\begin{array}{l}\text { Purchase } \\
\text { Intention }\end{array}$ & $\begin{array}{l}\text { Addiction towards } \\
\text { online mobile } \\
\text { games }(\mathrm{H} 2)\end{array}$ & $0.212^{* * *}$ & 0.077 & $0.366^{* * *}$ & 0.062 \\
\hline \multicolumn{6}{|c|}{ Indirect effects model } \\
\hline $\begin{array}{l}\text { Purchase } \\
\text { Intention }\end{array}$ & $\begin{array}{l}\text { Addiction towards } \\
\text { online mobile } \\
\text { games (H1) }\end{array}$ & $0.348^{* * *}$ & 0.053 & $0.348^{* * *}$ & 0.143 \\
\hline
\end{tabular}




\begin{tabular}{|c|c|c|c|c|c|}
\hline \multicolumn{6}{|c|}{ Table 6: ANOVA for male and female respondents } \\
\hline Factors & Male* $^{*}$ & Female* & F value & $\eta^{2}$ & $\begin{array}{c}\text { Mean } \\
\text { Difference bcf }\end{array}$ \\
\hline Salience & 3.63 & 2.82 & $284.16^{* *}$ & 0.399 & $0.805^{* * *}$ \\
\hline Tolerance & 3.86 & 2.99 & $259.89^{* *}$ & 0.378 & $0.868^{* * *}$ \\
\hline Mood Modification & 3.83 & 3.00 & $237.72^{* *}$ & 0.357 & $0.829^{* * *}$ \\
\hline Relapse & 3.77 & 2.87 & $272.92^{* *}$ & 0.389 & $0.902^{* * *}$ \\
\hline Withdrawal & 3.45 & 2.63 & $211.16^{* *}$ & 0.330 & $0.825^{* * *}$ \\
\hline Conflict & 3.59 & 2.62 & $263.97^{* *}$ & 0.381 & $0.972^{* * *}$ \\
\hline Problems & 4.02 & 3.10 & $236.31^{* *}$ & 0.356 & $0.926^{* * *}$ \\
\hline Purchase Intention & 3.06 & 2.66 & $35.87^{* *}$ & 0.077 & $0.407^{* * *}$ \\
\hline Loyalty & 3.39 & 2.79 & $143.15^{* *}$ & 0.251 & $0.601^{* * *}$ \\
\hline $\begin{array}{l}{ }^{*} \text { denotes the mean va } \\
{ }^{* *} \text { denotes the values } \\
{ }^{* * *} \text { denotes the value } \\
\eta^{2} \text { represents Eta Sq } \\
\text { bcf denotes mean diff }\end{array}$ & $\begin{array}{l}\text { observed } \\
\text { ignificant } \\
\text { significar } \\
=\text { SS }_{\text {betwee }} \\
\text { e after en }\end{array}$ & $\begin{array}{l}\text { om the fac } \\
\text { t } p<0.0001 \\
\text { at } p<0.05 \\
S_{\text {total }}\end{array}$ & $\begin{array}{l}\text { tor scores } \\
; d f=429\end{array}$ & )) & \\
\hline
\end{tabular}

